\title{
Freshwater fish's spatial patterns in isolated water springs in North-eastern Mexico
}

Jorge Palacio-Núñez ${ }^{1}$, José R. Verdú ${ }^{2}$, Catherine Numa², Daniel Jiménez-García ${ }^{3}$, Genaro Olmos Oropeza $^{1} \&$ Eduardo Galante ${ }^{2}$

1. Colegio de Postgraduados, Campus San Luis Potosí, Iturbide 73, Salinas de Hidalgo, S.L.P., 78600 México; jpalacio@colpos.mx,olmosg@colpos.mx

2. Centro Iberoamericano de la Biodiversidad (CIBIO), Universidad de Alicante, Carretera San Vicente del Raspeig s/n, San Vicente del Raspeig, Alicante, 03690 España; jr.verdu@ua.es, cnv1@alu.ua.es, galante@ua.es

3. Departamento de Agroecología y Ambiente, Instituto de Ciencias, Benemérita Universidad Autónoma de Puebla, 14 sur 6301, Col. San Manuel. Puebla, Pue.72570 México; jimenez.daniel77@gmail.com

Received 03-IV-2009. Corrected 20-IX-2009. Accepted 20-X-2009.

\begin{abstract}
The Media Luna lake-spring was selected as representative of all thermal or no thermal springs in the zone of Valley of Rioverde, a semi-arid vegetation in the North-eastern of Mexico. This system is inhabited by 11 fish species, of which six are native. Four of the native species are endemic to the region and threatened due to touristic pressure and to the introduction of exotic species. The objectives were to determine the characteristics that influence the spatial distribution of the fish species, to analyze their spatial distribution patterns, and to describe the relationships between the different species. The general aim was to establish some basis for the conservation of these fish communities and their habitat. Several sessions were initiated in 1992 through direct observation. Later, between 1998 and 1999 five systematically seasonal sampling sessions were conducted (54 subaquatic transects/session). Finally, the data was updated by sampling in summer 2002 and winter 2006. Through the analysis was performed only for endemics of the region, like Ataeniobius toweri Meek, Cualac tessellatus Miller, Cichlasoma bartoni Bean and C. labridens Pellegrin, in at least one life stage, showed correlation with habitat variables or with other species. For these species, patterns of spatial aggregation and association with other species were observed. These results show a certain degree of specialization of endemic species to some microhabitat characteristics, as well as a significant interaction with other native species which they coexist. In addition, some significant relations between endemic and alien species suggest an antagonist relation. Management actions focused in the touristic use of the spring represent the main threat for these species, followed by an adequate management of exotic species. This study provides basis for future responsible management of these wetlands, where tourism and conservation can be combined. Rev. Biol. Trop. 58 (1): $413-$ 426. Epub 2010 March 01.
\end{abstract}

Key words: endemic fishes, threatened fishes, Media Luna spring, spatial association, tourism impact.

Life distribution depends on various factors that cover very different spatial and temporal scales, from global to local (Nogués-Bravo 2003), and their interactions (Perry \& Dixon 2002). Some elements such as vegetation, topography and environment related alterations are also important for life distribution (SuárezSeoane et al. 2002). Frequently, those natural elements are altered or destroyed by human use, with negative repercussions on native biodiversity (Angermeier \& Schlosser 1995, Palacio-Núñez et al. 2007).

Freshwater systems are commonly high in biodiversity, with unique distribution patterns. These ecosystems are very susceptible; however, they have been subject to transformations, mostly to constant environmental degradation (Alan \& Flecker 1993, Cooperrider \& Noss 1994). Arid zones have, by definition, lack superficial water, and the scarce springs are 
likely to be isolated ecosystems, often with high content of solutes. This isolation favours particular environmental conditions, which promotes the existence of endemic fish species (Contreras-Balderas 1969).

Freshwater fishes encompass a high number of species and are present in a large range of habitat, sometimes with very specific conditions. Some species are sensitive to changes, while others survive in highly degraded conditions (Marrow \& Fischenich 2000). Arid land fishes tend to have a very restricted distribution, sometimes to only one spring (Contreras-Balderas 1969). The transformation of Mexican northern areas have been negatively affecting native ichtyofauna, resulting in the disappearance of some species, and most of those remaining are threatened (Contreras-Balderas 1969, Pérez-Arteaga et al. 2005). In this geographic region, two areas of special interest for wetlands that contain endemic fishes are: Cuatro Ciénegas, Coahuila, and the plains of Rioverde, San Luis Potosi (Contreras-Balderas 1969, Miller 1984). Both ecosystems are highly impacted by human activities in such a way that most of its species are threatened (PérezArteaga et al. 2005).

A common limitation of environmental studies in Mexico is the lack of information available on local communities, biodiversity loss rates, and habitat tolerance to human impact. Considering that each ecosystem has its own characteristics, resources and species distribution, studies should be site specific (Guisan \& Zimmermann 2000). On the other hand, in regards to fish, there is limited knowledge about interaction dynamics, and therefore, how the latter influence in the community (Palmer et al. 2003).

For the conservation of threatened species, the distribution patterns must be know in terms of environmental and biological aspects, as they both determine their long term survival (Root 1998). Normally, the spatially distribution of species is not random. Some population responses are given by the species' microhabitat preferences; however, it is difficult to determine the interrelations and other ecological processes that influence their distribution (Schoener 1974, Feinsinger et al. 1981, Dolédec et al. 2000, Maestre 2006). Presently, there is great interest in knowing the distribution patterns (Quero 2006). There are population models that can be used to relate demographics process and the environment, which are fundamental to develop management strategies (Root 1998), by determining the influence that different factors have towards the populations, such as habitat loss (Currie 2003). Predicting models used in ecology have been favoured by robust statistics and by geographic information systems (Guisan \& Zimmermann 2000). These models are frequently used to obtain patterns of distribution (Jarberg \& Guisan 2001), habitat selection and levels of coexistence among species (Leathwick \& Austin 2001, Suárez-Seoane et al. 2002).

An aim of the present study was to characterize the different elements which constitute the subaquatic landscape through the use of GIS, such as depth gradients, and subaquatic vegetation distribution and morphology. Consequently, the main objectives of this study are: a) to determine the environmental variables that influence spatial distribution of freshwater fishes in one isolated spring; b) to analyze distribution patterns and spatial associations existing between species of the same community; and c) to establish some suggestions for the conservation of these communities and their habitat.

\section{MATERIALS AND METHODS}

Study site: The study was conducted in one of the freshwater system of Valley of Rio Verde, San Luis Potosi, Mexico, in the border between Neartic and Neotropic zones. The Media Luna system is the biggest and most complex in this valley. It is located between $\mathrm{X}$ UTM: 393723-395317, and Y UTM: 24176472418070 coordinates, zone $14 \mathrm{~N}$, with an average of $1000 \mathrm{~m}$ in elevation. It is a complex that consists in two spring-lakes (Media Luna and Los Anteojitos), various channels or rivers of permanent water, two seasonal lakes, 
and flooding zones with lateral infiltrations which maintain a wet environment at variable distances from the source. This place contrasts with the aridity of the plain. The Media Luna lake is formed by six spring craters providing a constant flow of about $50001 . \mathrm{s}^{-1}$ crystalline thermal water. The bigger crater is $36 \mathrm{~m}$ deep (Miller 1984, Labarthe et al. 1989).

This system has a long configuration; the main portion is extended longitudinally from West to East (Fig. 1). This system is subject to a variable anthropic pressure, the strongest in the West portion that comprises the lake-spring and a channel towards the North. The aquatic vegetation, composed only by Nymphaea sp., tends to cover completely the substrate in a depth lower than $13 \mathrm{~m}$; however, the touristic activity on the area disturbs and eliminates it (PalacioNúñez et. al 2007). This vegetation shows two morphological types: 1) "carpet shape": plants with dense covering forming a thick carpet under the water, and 2) "floating leaves": which are more disperse subaquatic plants with some leaves that float. In any of its forms, there are marked differences between the subaquatic landscapes according to anthropic pressure levels (Palacio-Núñez 1997).

Cartography: The design of the cartography for the study site was obtained from the orthophoto F14-C16f with scale 1:50 000 (INEGI). The polygons for the construction of the maps were made with Cartalinx 1.2, and were exported to Arcview GIS 3.2 for their analysis and manipulation. A grid (tile) was built out of 4249 grid boxes of $2 \times 2 \mathrm{~m}$.

Sampling design: The fish sampling initiated in 1992 through direct observation, considering the sighting effort for each species. From 1998, systematically sampling sessions began and were conducted in: spring and summer 1998, winter 1998-1999, summer and autumn of 1999, and were updated by sampling in summer 2002 and winter 2006. This systematic sampling was conducted by adapting

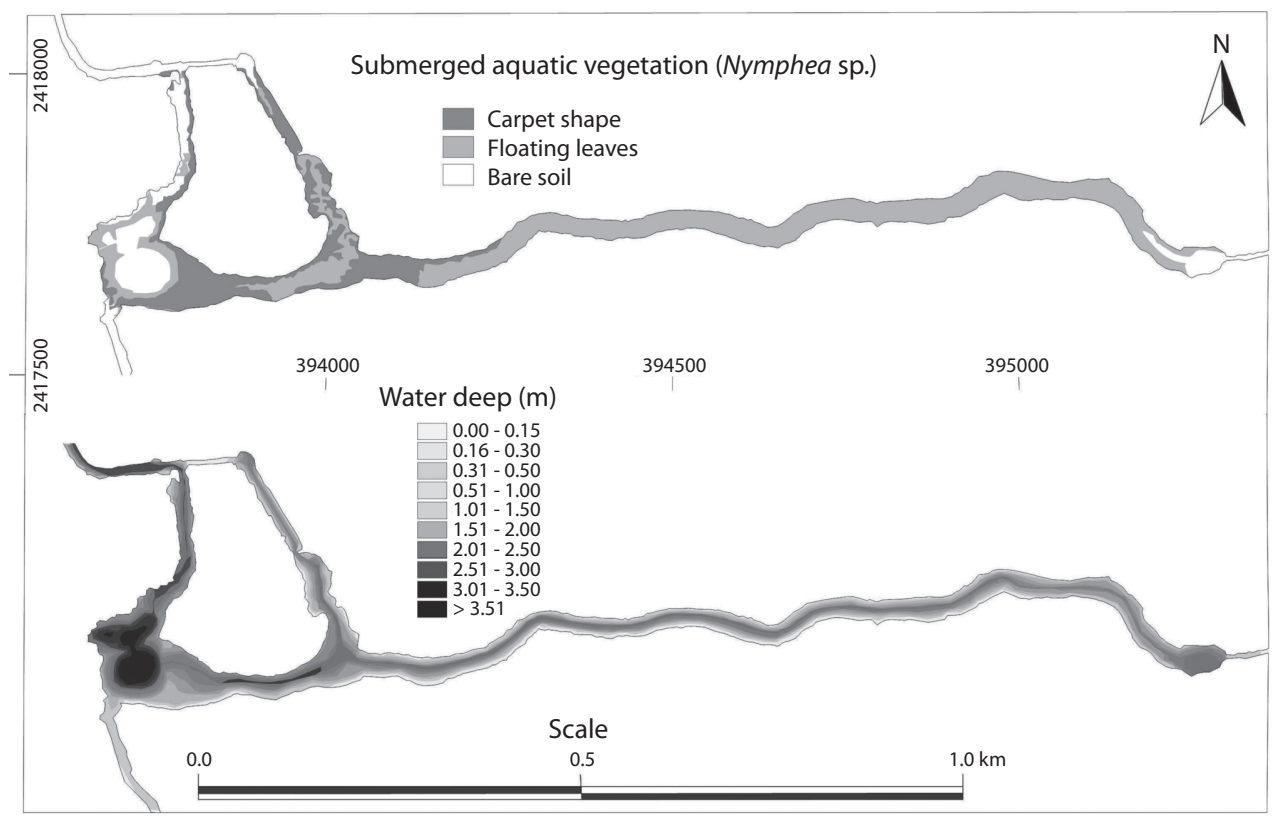

Fig. 1. Study area. The first image presents the distribution of submerged aquatic vegetation represented by Nymphaea sp. in its two different morphological types. The N, NW and extreme E are free from vegetation due to human pressure. In the second image, the different levels of water depth are represented (according to fish distribution). The human-influenced areas show steep slopes while the natural portions are of graduate slopes. 
the Finnish transect of Järvinen and Väisänen (Tellería 1986) for underwater use through snorkelling. In each session, there was a total of $\mathrm{n}=54$ transects with a fixed band of $2 \mathrm{~m}$, evenly distributed throughout the system, 51 of these transects had a $10 \mathrm{~m}$ length, which covered an area of $20 \mathrm{~m}^{2}$ each, including 5 grid boxes. For the three remaining transects the length was $8 \mathrm{~m}$ (the channel's width). In total, 275 grid boxes were considered.

From an ecological and evolutionary point of view, body size manifests itself as one of the most important attributes (Werner \& Guilliam 1984). Some population with specimens of different height, age or class, can behave as different species (Gotelli 1997). In fishes, the difference in size between ages is often big and, in general, the models of population dynamics for this group are more appropriate if they are based on the size and not on the age (Werner \& Guilliam 1984). Therefore, the fish population was analyzed separately in different age classes: adult, juvenile and fry. Transects were distributed perpendicularly to the riverfront to include gradients of depth and aquatic vegetation and fish abundance was considered in reference to the area corresponding to each of the grid boxes (Palacio-Núñez et al. 2007).

Although there are other fish species in the Media Luna spring, for the purpose of this study only diurnal species were observed.

Statistical analysis: Generalized linear models (GLZ) with Poisson distribution and logarithmic link function were constructed to analyze the relationships between the species abundance as the dependent variable, and biotic and abiotic factors as explanatory variables. The following set of variables was documented for each of the $4249 \mathrm{~m} \mathrm{2x} 2$ boxes: a) area in square meters by type of subaquatic vegetation: bare soil, "carpet shape" type vegetation, or "floating leaves" type, b) abundance of the fish species by three age categories, adult (Ad), juvenile (Ju) and fry (Fr), c) area by eight types of depth in square meters (see Fig. 1): seven depth types for fish use $(0.0-0.15 \mathrm{~m}, 0.16$ $0.30 \mathrm{~m} ; 0.31-0.50 \mathrm{~m}, 0.51-1.00 \mathrm{~m}, 1.01-1.5 \mathrm{~m}$,
$1.51-2.50 \mathrm{~m},>2.51 \mathrm{~m}$ ), and one more for subaquatic vegetation growth restriction $(>13.01$ m). Finally, plot location (longitude UTM X and latitude UTM Y) was included to consider the spatial features, and the effect of historical, biotic or environment variables otherwise were not directly considered (Legendre \& Legendre 1998). The STATISTICA Software 6.0. (StatSoft Inc. 2001) was used for all statistical analysis. Spatial variables were included in the analysis to identify spatial patterns related to other factors different to the selected variables. In this case the $\mathrm{X}$ axis coincides with a perturbation gradient where submerged and riparian vegetation are increased to the Eastern points, where tourism activity is lower.

Species with significant relationships in the models were selected to examine a possible aggregation spatial patterns, and association (or disassociation) between pairs of species. Sadie was developed for the spatial analysis of count data. Each count, $c \mathrm{k}$, is assumed to be spatially-referenced at a specified location in two dimensions $(x, y)$, moreover the set of locations may be irregularly spaced and not on a grid (Perry 1995, Perry et al. 1996, Perry 1998). First, SADIE was used to calculate the aggregation index (Ia) between the different pairs. The (Ia) is based on the total distance (D) that individuals would have to move in order to occupy for each a single sample (distance to crowding) or the total distance necessary to achieve the same number of points in each sample unit (distance to regularity) divided by the mean from randomization. An aggregated variable has an $I a>1$ (if $p<0.05$ ), a spatially random variable has an $I a=1$, while a regular distributed variable has an $I a<1$. Additionally, the spatial association or disassociation values between pairs of species were calculated with SADIE. The overall spatial association (X) was measured obtained from the measures of local association $\left(\chi_{\mathrm{k}}\right)$. Results of $\chi_{\mathrm{k}}$ were mapped using interpolation techniques (krigging method) implemented in the package Arcview 3.2 (ESRI 1999) for a more clear illustration of the obtained spatial patterns. 


\section{RESULTS}

The Media Luna spring is inhabited by 11 diurnal fish species (Table 1): six native ones, four of them are endemic to the Valley of Rioverde, one endemic to the region and one native, one of which are threatened and four endangered. The remaining five species are exotic; and is important to note that one of them is critically endangered in its native habitat.

Between summer of 1992 and winter of 2006, some fluctuations in populations were observed. An increase (1992 to 1995) and subsequent decline in the abundance of Cichlasoma cyanoguttatum Bird and Girard and Poecilia latipunctata Meek (1996 to 2006) was registered. Also from 1995 a marked increase of Poecilia mexicana Steindachner was observed simultaneously that a decrease of Ataeniobius toweri Meek and P. latipunctata.

Between 1997 and 1999 there was a relatively stable population, and therefore the data obtained during this period was used to determinate the mean abundance of each species related to their life stage and to establish the basis for further analysis.

Only those species endemic to the region: A. toweri, C. tessellatus, C. bartoni and
Cichlasoma labridens Pellegrin, in at least one life stage, showed correlation with a habitat variable or with other species (Table 2). $A$. toweri showed correlations in its three stages through analysis GLZ.

For $A$. toweri Ad and Ju, there was a positive correlation with the distribution along the longitudinal distribution ( $\mathrm{X}$ axe), being the more evident in the Ju stage (Table 2). A. toweri Ju also had a positive relationship with less than $0.3 \mathrm{~m}$ water depth. There was a relationship between A. toweri Fr and P. mexicana Fr. There was also a positive correlation between $A$. toweri Ad with $C$. tessellatus Ad. On the other hand, $C$. tessellatus Ad reaffirmed its correlation with $A$. toweri Ad, and showed a positive correlation with the Ad of $C$. cyanoguttatum and $C$. labridens.

C. bartoni Fr correlated with bare soil and C. cyanoguttatum Ad. In addition, C. labridens showed only a correlation between $\mathrm{Ad}$ and $\mathrm{Ju}$ of its own species (see Table 2).

The results for spatial aggregation showed a significant aggregation rates (Ia) only for $A$. toweri $\mathrm{Ad}, C$. labridens $\mathrm{Ad}, C$. tessellates $\mathrm{Ad}$ and $\mathrm{Ju}$, and $C$. cyanoguttatum Ad (Table 3 ).

The analysis of spatial association conducted with fish species that showed relation to other species or different age class of the same

TABLE 1

List of fish species present in the daytime system of the Media Luna, with their distribution (D) and extinction risk category (R) according to the Mexican Official Standard - 059 (INE 2002). The mean abundance of each species is related to their life stage between spring 1998 and autumn 1999

\begin{tabular}{|c|c|c|c|c|c|c|}
\hline \multirow{2}{*}{ Family } & \multirow[t]{2}{*}{ Species } & \multirow[t]{2}{*}{$\mathrm{D}$} & \multirow[t]{2}{*}{$\mathrm{R}$} & \multicolumn{3}{|c|}{ Mean abundance } \\
\hline & & & & Adult (Ad) & Juvenile (Ju) & Fry $(\mathrm{Fr})$ \\
\hline Characidae & Astyanax mexicanus Filippi & 3 & NL & 10409 & 6216 & 280 \\
\hline \multirow[t]{4}{*}{ Cichlidae } & Cichlasoma bartoni Bean & 1 & $\mathrm{E}$ & 977 & 68 & 1861 \\
\hline & C. cyanoguttatum Bird and Girard & 4 & NL & 356 & 505 & 58 \\
\hline & C. labridens Pellegrin & 2 & $\mathrm{E}$ & 5284 & 3458 & 726 \\
\hline & Oreochromis sp. & 5 & NL & 2190 & 2168 & 1130 \\
\hline Cyprinodontidae & Cualac tessellatus Miller & 1 & $\mathrm{E}$ & 12031 & 6348 & 400 \\
\hline Cyprinidae & Dionda dichroma Hubbs and Miller & 1 & $\mathrm{~T}$ & 43 & 0 & 0 \\
\hline Goodeidae & Ataeniobius toweri Meek & 1 & $\mathrm{E}$ & 4428 & 2405 & 340 \\
\hline \multirow[t]{3}{*}{ Poecilidae } & Gambusia panuco Hubbs & 4 & NL & 3544 & 3080 & 2015 \\
\hline & Poecilia latipunctata Meek & 4 & $\mathrm{CE}$ & 4600 & 476 & 269 \\
\hline & P. mexicana Steindachner & 4 & NL & 2695 & 961 & 548 \\
\hline
\end{tabular}

$\mathbf{D}=$ distribution: $\mathbf{1}=$ Endemic to the Valley of Rioverde, $\mathbf{2}=$ Endemic to the region, $\mathbf{3}=$ Native with wide natural distribution, 4 = Native to NE of Mexico, introduced to Media Luna, $\mathbf{5}$ = Native of another country. Based on the Mexican Fishes List (Espinosa-Pérez et al. 1993). $\mathbf{R}=$ Risk: $\mathbf{N L}=$ not listed, $\mathbf{T}=$ threatened, $\mathbf{E}=$ endangered, $\mathbf{C E}=$ critically endangered. 
TABLE 2

Correlation between fish species of the Media Luna with habitat variables and with other species

\begin{tabular}{|c|c|c|c|c|c|}
\hline Species and age & Level of: & Estimated & Standard & Wald's & $\mathrm{p}$ \\
\hline & & $\beta$ & error & statistic & \\
\hline \multirow[t]{2}{*}{ A. toweri Ad } & UTM $\mathrm{X}$ axis & 0.001 & 0.001 & 6.266 & 0.012 \\
\hline & C. tessellatus Ad & 1.336 & 0.450 & 8.793 & 0.003 \\
\hline \multirow[t]{2}{*}{ A. toweri $\mathrm{Ju}$} & UTM $\mathrm{X}$ axis & 0.002 & 0.001 & 13.287 & 0.000 \\
\hline & Deep $<0.3 \mathrm{~m}$ & 0.527 & 0.204 & 6.684 & 0.010 \\
\hline A. toweri $\mathrm{Fr}$ & P. mexicana $\mathrm{Fr}$ & 5.405 & 1.580 & 11.697 & 0.002 \\
\hline \multirow[t]{3}{*}{ C. tessellatus Ad } & A. toweri Ad & 1.545 & 0.478 & 10.453 & 0.001 \\
\hline & C. cyanoguttatum Ad & 7.584 & 2.668 & 8.080 & 0.004 \\
\hline & C. labridens Ad & 1.894 & 0.621 & 9.309 & 0.002 \\
\hline C. tessellatus $\mathrm{Ju}$ & C. tessellatus Ad & 0.938 & 0.372 & 6.371 & 0.012 \\
\hline \multirow[t]{2}{*}{ C. bartoni $\mathrm{Fr}$} & Bare soil & 0.691 & 0.181 & 14.615 & 0.000 \\
\hline & C. cyanoguttatum Ad & 12.181 & 5.389 & 5.109 & 0.024 \\
\hline C. labridens Ad & C. labridens $\mathrm{Ju}$ & 2.360 & 0.839 & 7.917 & 0.005 \\
\hline C. labridens $\mathrm{Ju}$ & C. labridens Ad & 2.815 & 0.941 & 8.946 & 0.003 \\
\hline
\end{tabular}

TABLE 3

Aggregation index for the six fish species and their life stage of the Media Luna. Half of the aggregation rates were not significant $(p>0.05)$

$\begin{array}{lcc}\text { Species and age } & \text { Ia } & p \\ \text { A. toweri } \mathrm{Ad} & 1.683 & 0.0327 \\ \text { A. toweri } \mathrm{Fr} & 1.112 & 0.2397 \\ \text { C. bartoni } \mathrm{Fr} & 1.392 & 0.0965 \\ \text { C. labridens } \mathrm{Fr} & 0.928 & 0.5155 \\ \text { C. labridens } \mathrm{Ju} & 1.543 & 0.0595 \\ \text { C. labridens } \mathrm{Ad} & 2.479 & 0.0002 \\ \text { C. tessellatus } \mathrm{Ju} & 1.819 & 0.0235 \\ \text { C. tessellatus } \mathrm{Ad} & 2.307 & 0.001 \\ \text { C. cyanoguttatum Ad } & 1.722 & 0.0315 \\ \text { P. mexicana } \mathrm{Fr} & 0.827 & 0.6933\end{array}$

species (see Table 2), shows that only A. toweri Ad with $C$. tessellates Ad, A. toweri Fr with $P$. mexicana Fr, C. bartoni Fr with C. cyanoguttatum $\mathrm{Ad}$, and the association between $\mathrm{Ad}$ and $\mathrm{Ju}$ of $C$. tessellatus have a significant association degree (X) (Table 4).

The interrelationships of significant association of Table 4 are shown on association - dissociation maps. For none of the four cases there was a significant dissociation, and in all of them there were five ranges of association values.

The association between pairs of species was observed on portions of the Media Luna where the two participating species in each

TABLE 4

Association degree between six combinations pairs between species or age classes of fish of the Media Luna. Only three species showed a significant association with other species, C. tessellatus only correlated significantly between the juvenile stage and the adult stage of its own species. Only the results between C. labridens Ju and Fr show dissociation, but this result was not significant

$\begin{array}{lcc}\text { Association: } & \mathrm{X} & p \\ \text { A. toweri } \mathrm{Ad}-\text { C. tessellatus Ad } & 0.5696 & 0.0013 \\ \text { A. toweri } \mathrm{Fr}-\text { P. mexicana } \mathrm{Fr} & 0.6056 & 0.0004 \\ \text { C. bartoni } \mathrm{Fr} \text { - C. cyanoguttatum Ad } & 0.3842 & 0.0022 \\ \text { C. labridens } \mathrm{Ju} \text { - C. labridens Fr } & -0.0701 & 0.6762 \\ \text { C. tessellatus Ad - C. cyanoguttatum Ad } & 0.1965 & 0.0761 \\ \text { C. tessellatus Ju - C. tessellatus Ad } & 0.5493 & 0.0004\end{array}$


association coexist and are abundant. The association between $A$. toweri Ad and $C$. tessellates Ad can be seen almost everywhere in the system, but a significant association is only present in four areas (Fig. 2). The association between A. toweri $\mathrm{Fr}$ and $P$. mexicana $\mathrm{Fr}$ is observed in a large portion of the system, but significantly in only five small portions (Fig. 3). Between $C$. tessellatus $\mathrm{Ju}$ and Ad (Fig. 4), the association can be observed at different points distributed throughout the system, but significantly only occurs in four areas. Finally, the association between $C$. bartoni Fr and C. cyanoguttatum Ad occurred in the larger portion of the system,

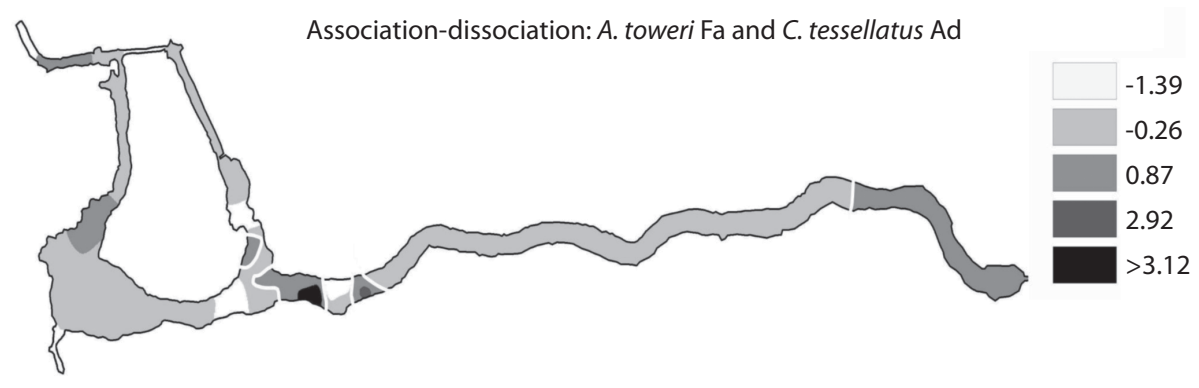

Fig. 2. Association-dissociation for the relationship between A. toweri Ad and C. tessellatus Ad and the values $\left(\chi^{2}\right)$ ranged from -1.39 to 4.25 with critical values from -2.76 (significant local dissociation) to 2.92 (significant local association) at a confidence level of $95 \%$. The significant association is represented with darker tones bordered by white lines. This occurred in areas with high cover of Nymphaea sp.

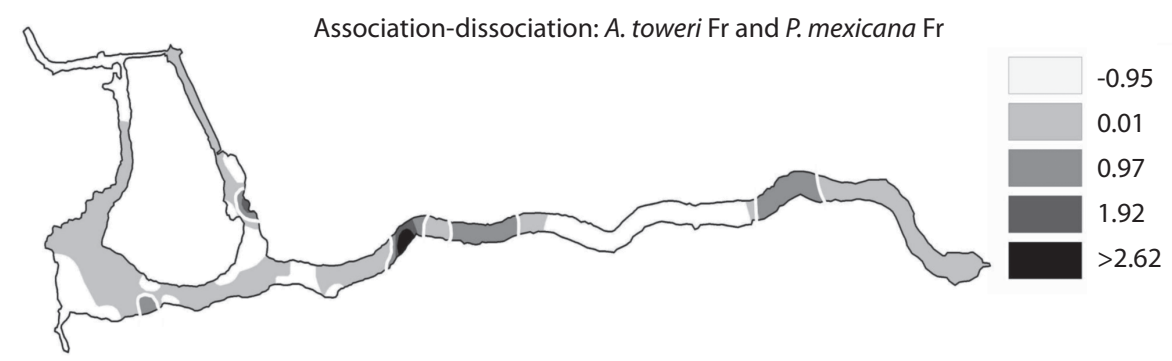

Fig. 3. Association-dissociation for the relationship between A. toweri Fr and P. mexicana Fr and the values $\left(\chi^{2}\right)$ ranged from -0.95 to 3.83 with critical values from -2.63 (significant local dissociation) to 2.62 (significant local association) at a confidence level of $95 \%$. The significant association is represented with darker tones bordered by white lines.

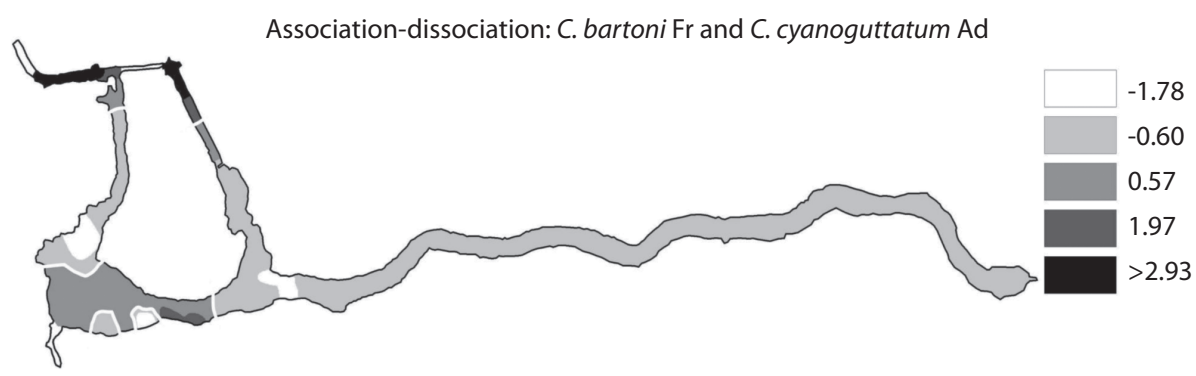

Fig. 4. Association-dissociation for the relationship between C. tessellatus Ju and Ad and the values $\left(\chi^{2}\right)$ ranged from -0.86 to 3.99 with critical values from -2.45 (significant local dissociation) to 2.56 (significant local association) at a confidence level of $95 \%$. The significant association is represented with darker tones bordered by white lines. 


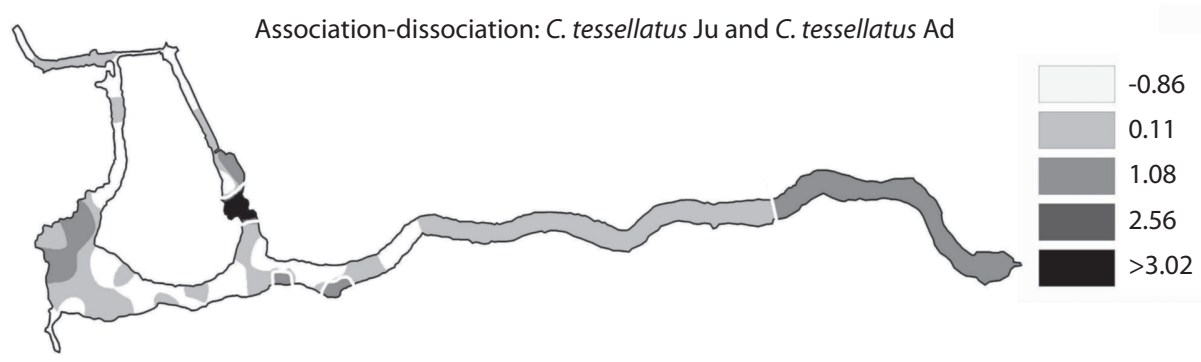

Fig. 5. Association-dissociation for the relationship between C. bartoni Fr and C. cyanoguttatum Ad and the values $(\chi 2)$ ranged from -1.78 to 4.11 with critical values from -1.92 (significant local dissociation) to 1.97 (significant local association) at a confidence level of $95 \%$. The significant association is represented with darker tones bordered by white lines.

but significantly only in the three portions where both species are abundant (Fig. 5).

\section{DISCUSSION}

The Media Luna system is inhabited by the fish species Ictalurus mexicanus Meek, which is endemic of the region, and the introduced $I$. furcatus Valenciennes. Both species have nocturnal habits (Soto Galera 2003d); thus, they were not detected in the sampling because they hide during light hours. The possible implication of these species on the diurnal species distribution was not considered in this study.

The body size difference between age classes (Werner \& Guilliam 1984) or between species influences the fish distribution (Purchase \& Hutchings 2008, Prchalová et al. 2009), which is reflected in the Media Luna species. Regarding the size difference among them, Ictalurus sp. grows more than all other fish species (Soto Galera 2003d), and the cichlids, native or introduced, have a larger size than other non-cichlid species. Eventually, fry and juveniles of all species may have similar sizes (Soto Galera 2003a,b,c, PalacioNúñez, pers. obs.). Most of Media Luna species changes its spatial distribution according to their age class. There are divergences between the cichlids and non-cichlids fry development (Palacio-Núñez, pers. obs.).

The spatial distribution patterns of fish group are poorly studied. Most of the research has been focused in commercial or sport big species. Little non-commercial species have received the poorest attention. However, some information regarding the methods to study this group is available. Also, some guides and useful results can be used for comparison of the species distribution. Several authors used prediction models for freshwater fish populations, including distribution patterns and predictive performance of fish distribution. Different prediction models have demonstrated to be effective. Thus, it is possible to predict the suitability of sites as habitats for a given fish species using estimated natural values of local habitat variables (Mugodo et al. 2006). Generally, these studies were conducted in big rivers or lakes, where fish species distribution can be highly influenced by upstream or downstream location and seasonality (Winemiller \& Pianka 1990, Chick et al. 2006, Buisson \& Grenouillet 2009), or bioregional distribution (Grownsa \& Westb 2008). Those aspects have not similarity with Media Luna conditions because this system is small and the thermal water flow remains constant along the year. Instead, the landscape underwater conditions (McIvor \& Odum 1998) have strong influence over some species, such as $A$. toweri and $C$. bartoni. According to the results, fish species in the Media Luna do not have a distribution in all variants within the system, except these generalist A. mexicanus, C. tessellatus, Oreochromis sp. and $C$. labridens, all in their adult state. Juveniles are more restricted and the fry evens more. 
It is important to note that only four species showed a significant correlation with their habitat or with other species, these are the endemic A. toweri, C. tessellatus, C. bartoni and $C$. labridens. Aggregate indices and spatial patterns of association with other species also resulted significant. In some cases this association was observed only at some points in their life stage, which stands out their adaptation to a specific habitat at a particular time of its life.

The relationship of some species to a particular habitat has led to the design of proposals for habitat indicator species. A. toweri has been proposed as a bioindicator species in the system of the Media Luna, according to the quality of habitat involving high coverage of submerged vegetation (Palacio-Núñez et al. 2007). The correlation with the longitudinal distribution to the East obtained in this study confirms the affinity of this species towards sites with abundant submerged vegetation, away from the human influenced sites with steep slopes and less riparian vegetation. A. toweri $\mathrm{Fr}$ showed a significant association with Fr of $P$. mexicana. This fact is noted in areas with gentle slopes where very low depths $(<0.3 \mathrm{~m})$ and abundant aquatic vegetation are combined.

The only significant association between Ad fishes occurred between species of endemic genera of the Valley of Rioverde: A. toweri and $C$. tessellatus, it often shared by the same group when individuals have similar size. This association can be seen almost everywhere in the system, but more frequent in portions of the habitat with abundant submerged vegetation (Palacio-Núñez pers. obs.). Both species have similar eating habits (Soto Galera 2003 a,b) and their trophic differentiation should be grounds for future research.

Among C. tessellatus $\mathrm{Ju}$ and Ad shows association in many parts of the system, but occurs only significantly in four areas with abundant vegetation and intermediate benefice depths for both states of this species. C. bartoni is another species proposed as bioindicator of the state of the habitat in this type of springs, but in places without aquatic vegetation, and therefore it has benefited from the effect of vegetation removal for touristic use, showing the greatest abundance at the sites used by tourism (Palacio-Núñez et al. 2007).

Within these results, C. bartoni $\mathrm{Fr}$, showed a positive correlation with the bare soil, confirming the importance of the latter for this species. This species also showed a high correlation with $C$. cyanoguttatum $\mathrm{Ad}$, and even if this association is seen in most of the Media Luna system, it only appears significantly in three portions, which include some areas with high vegetation coverage, but also in more human influenced zones. It is worth mentioning that throughout the study period, patches of bare soil caused by the aging of several plants together were registered. Breeding pairs of C. bartoni were commonly observed in these patches. However, some patches were occupied also by couples of $C$. cyanoguttatum. These results suggest that this introduced species is competing for the microhabitat required by $C$. bartoni to breed. Additional field data showed that $C$. cyanoguttatum has greater average size than $C$. bartoni, and is also a more aggressive predator (on several occasions was seen devouring other cichlids Ad). This species could depredate not just the Fr, but also parents, so it is not considered a positive association.

The dominance of one or several competing species has also implications on the fish spatial distribution (Baut \& Muller 1998, Bornette et al. 2001). Overall, the introduction of aquatic species is a growing problem, particularly when they adversely affect native species. This environmental problem caused by invasive species has been increasing in many parts of the world (Parker et al. 1999, Campbell et al. 2005, Clavero \& García-Berthou 2006, Olden et al. 2006, Rahel \& Olden 2008, Ribeiro et al. 2008, Ribeiro et al. 2009), and the Media Luna system is not the exception. Competition between two species can lead to population decline of one of them (depressive competition), which is a very common result in many cases (Mac Nally 1983, Rahel \& Olden 2008, Ribeiro et al. 2008, Ribeiro et al. 2009). The findings provide evidence of overlapping between two endemic species and two non-natives. The 
temporal variability in community's abundance decreases with the increase in species richness (Vogt et al. 2006). Additionally, the number of native fish decreased with increasing nonnative fish, where nonnative and native fish habitats overlap and predation on and competition with native fish is likely to occur (Kamerath et al., 2008). Species inhabiting wetlands in arid zones usually evolved isolated, or in the company of few species; thus, they have no experience about interrelation with new species and are particularly susceptible to non-native species invasions (Contreras-Balderas 1969). The arrival of a new species can create a total mismatch. In addition to the pressure exerted by introduced species on native species, many human actions poorly managed have had an impact on the ichtyofauna of the Media Luna. The strong pressure from tourism creates special circumstances that are not present in other springs in the area, or has had less pressure.

For purposes of conservation, the spatial analysis in this study provides relevant information about the punctual sites for significant associations between pairs of species by age classes. These findings, collated with data on submerged vegetation distribution and water depth, help to infer the importance of these variables on the species. This is especially important in the case of Fr of the endemic and endangered species. It allows determining the most important areas to them, which ensure the viability of the species in the long term.

The Nymphaea plants are very fragile and tourists destroy or damage it. The visitor pressure on the substrate also eliminates the gentle slopes required by $A$. toweri Fr. Media Luna Park owners and managers are rural local people, without an adequate environmental culture. They manage this place according their own criteria; in a high tourism season they apply pesticides, often directly to water, to eliminate mosquitoes, and aquatic and riparian vegetation in some greatest use areas (Palacio-Núñez 1997). Although there is a low damage in the East portion and a partial or total recuperation occurs during the low tourism season, the threat for the habitat remains constant (PalacioNúñez, pers. obs.).

Similar conditions of submerged vegetation and depth gradients are present in at least five more springs in the area: Los Anteojitos, Palma Larga, Los Peroles, La Peña and El Sabinito. All springs have some different fish species composition. The Media Luna has (or had) a greatest diversity and growing impact of tourism, all their observed springs share several endemic (and non-endemic) species. Although there are differences and similarities among water springs each one must be considered individually (Guisan \& Zimmermann 2000).

The tourism industry have positive socioeconomic impacts specially in arid environments, but have negative environmental impacts such as the fish habitat destruction, pollution and poor waste management (Mbaiwa 2003). For the combination of tourism use and conservation, it is essential to understand the biology and habitat requirements of fish species and to design appropriate monitoring surveys that adequately assess the status of the fish populations, in various life stages against pre-set targets. Follow up on programs and results evaluation of the demographic structure, and perform mapping of the interest species distribution within each portion of the wetlands (Kleynhans 1999, Cowx et al. 2009). It is essential that managers understand the importance of the Media Luna specific results and, in the future, avoid the application of pesticides, the removal of native vegetation, and the introduction of new species in the springs of this and other areas. The added value for tourism potential given by the subaquatic landscapes, due both by fish and aquatic vegetation has not been considered or assessed. Also, it is necessary to enforce the rules for tourist use and promote tourist environmental education.

Most changes in the water springs of Rioverde Valley that affected fish population were not documented. Nevertheless, the population size fluctuation in Media Luna native fish species is documented at some degree. Gregg and Miller (cited by Soto Galera 2003c) mentioned that for the first half of the 20th Century, the 
most abundant species were $C$. bartoni, $C$. labridens and A. mexicanus. Based on this information, it can be inferred that, at least since 1992, A. mexicanus remains abundant, while $A$. toweri and, especially $C$. tessellates, had a marked population increase, maybe without important change in C. labridens population. There is no evidence of changes in the spatial distribution of any species, in any of their age class, except for the changes caused by local extinctions. When there are adaptive advantages, the population of nonnative species can spread if they are not controlled (Kamerath1 et al., 2008). By March 2009, with the exception of $D$. dichroma (now locally extinct), all species populations showed a recovery after the large decline in 2006. However, for the nonnative species, $P$. mexicana, . latipunctata, C. cyanoguttatum and Oreochromis sp. the population increase and was the highest. Now, it is necessary a nonnative species control campaign. The unique nature of this place should be regarded as an essential part of tourist attraction. Decremented or now locally extinct species in Media Luna as C. tessellates, C. bartoni, C. labridens, D. mandibularis and D. dichroma are present in other reservoirs populations from which individuals are available for the Media Luna repopulation, but there must be a responsible management to ensure the future of these and other species.

\section{ACKNOWLEDGMENTS}

We thank J. Jesús Enríquez who collaborated in field research. This study was partially supported by the AECID, Agencia Española de Cooperación Internacional para el Desarrollo (PCI projects A-1870/04, A-1870/05), a grant MAE-AECID to J. Palacio-Núñez (No. 32342) and also by institutional resources of Colegio de Postgraduados, Campus San Luis Potosí.

\section{RESUMEN}

Este estudio se enfocó en los peces de un sistema dulceacuícola en el noreste de México, donde habitan seis especies nativas (cuatro endémicas amenazadas) y cinco exóticas. El objetivo fue establecer los patrones que determinan la distribución espacial, así como las interrelaciones de las especies. Los datos se basan en sesiones de observación directa desde 1992; entre 1998 y 1999 se llevó a cabo un muestreo sistematizado mediante transectos subacuáticos en cinco sesiones estacionales (54 transectos/ sesión), con sesiones adicionales en 2002 y 2006. Sólo las especies endémicas de la región: Ataeniobius toweri, Cualac tessellatus, Cichlasoma bartoni y C. labridens, en al menos un estadio de vida, mostraron correlación significativa con variables del hábitat o con otras especies. También mostraron patrones de agregación y asociación con otras especies nativas o introducidas. Existe especialización de los endémicos a las condiciones de su microhábitat, así como interacciones significativas con otras especies. Acciones inadecuadas para promover el turismo representaron la mayor amenaza por destrucción del hábitat, endémicos tales como $A$, toweri y $C$. bartoni enfrentan solapamiento con especies introducidas, sobre todo en sus sitios de crianza. Este estudio aporta bases para un manejo responsable de estos humedales, donde turismo y conservación pueden combinarse.

Palabras clave: peces endémicos, peces amenazados, manantial de la Media Luna, asociación espacial, impacto por turismo.

\section{REFERENCES}

Alan, J.D. \& A.S. Flecker. 1993. Biodiversity conservation in running waters. BioScience 43: 32-44.

Angermeier, P. \& I. Schlosser. 1995. Conserving aquatic biodiversity: beyond species and populations. Am. Fish. Soc. Symp. 17: 402-414.

Angermeier, P.L. \& M.R. Winston. 1999. Characterizing fish community across Virginia Landscapes: prerequisite for conservation. Ecol. Appl. 9: 335-349

Baut, G.T. \& S. Muller. 1998. The impact of eutrophication on macrophyte diversity in weakly mineralized streams in the Northern Vosges mountains (NE France). Biod. Conserv. 7: 1051-1068.

Bornette, G., H. Piegay, A. Citterio, C. Amoros \& V. Godreau. 2001. Aquatic plant diversity in four river floodplains: a comparison at two hierarchical levels. Biod. Conserv. 10: 1683-1701.

Buisson, L. \& G. Grenouillet. 2009. Contrasted impacts of climate change on streams fish assemblages along environmental gradient. Diversity Distrib. 15: 613626.

Campbell, L., S.B. Wandera, R.J. Thacker, D.G. Dixon \& R.E. Hecky. 2005. Trophic niche segregation in the 
Nilotic ichthyofauna of Lake Albert (Uganda, Africa). Environ. Biol. Fish. 74: 247-260.

Clavero, M. \& E. García-Berthou. 2006. Homogenization dynamics and introduction routes of invasive freshwater fish in the Iberian Peninsula. Ecol. Appl. 16: 2313-2324.

Contreras-Balderas, S. 1969. Perspectivas de la ictiofauna en las zonas áridas del norte de México, pp. 293-304. In ICASALS, Texas, Tech. Publ. 3. Memorias - Primer Simposio Internacional de Aumento de Producción en Zonas Áridas. USA.

Cooperrider, A. \& R. Noss. 1994. Saving aquatic biodiversity. Wild Earth Spring 54-64.

Cowx, I.G., J.P. Harvey, R.A. Noble \& A.D. Nunn. 2009. Establishing survey and monitoring protocols for the assessment of conservation status of fish populations in river Special Areas of Conservation in the UK. Aquatic Conserv. Mar. Freshw. Ecosyst. 19: 96-103.

Currie, D. J. 2003. Conservation of endangered species and patterns and propensities of biodiversity. C.R. Biol. 326: S98-S103.

Dolédec, S., D. Chessel \& C. Gimaret-Carpenter. 2000. Niche separation in community analysis: a new method. Ecol. Soc. Am. 81: 2914-2927.

ESRI. 1999. Arcview GIS 3.2. Environmental System Research Institute, Inc., New York, USA.

Feinsinger, P., E.E. Spears \& R.W. Poole. 1981. A simple measure of niche breadth. Ecology 62: 69-76.

Gotelli, N.J. 1997. Competition and coexistence of larval ant lions. Ecology 78: 1761-1773.

Grevilliot, F., L. Frebs \& S. Muller. 1998. Comparative importance and interference of hydrological conditions and soil nutrient gradients in floristic biodiversity in flood meadows. Biod. Conserv. 7: 1495-1520.

Grownsa, I. \& G. Westb. 2008. Classification of aquatic bioregions through the use of distributional modelling of freshwater fish. Ecol. Model. 217: 79-86.

Guisan, A. \& N.E. Zimmermann. 2000. Predictive habitat distribution models in ecology. Ecol. Model. 135: 147-186.

Jarberg, C. \& A. Guisan. 2001. Modelling the distribution of bats in relation to landscape structure in a temperate mountain environment. J. Appl. Ecol. 38: 1169-1181.
Kamerath, M., S. Chandra1 \& B.C. Allen. 2008. Distribution and impacts of warm water invasive fish in Lake Tahoe, USA. Aquat. Inv. 3: 35-41.

Labarthe, G., M. Tristán, R. Aguillón, L.S. Jiménez \& A. Romero. 1989. Cartografía Geológica 1:50 000 de las hojas El Refugio y Mineral El Realito, Estados de San Luis Potosí y Guanajuato. U.A.S.L.P., Instituto de Geología. Folleto Técnico No 12. San Luis Potosí, México.

Leathwick, J.R. \& M.P. Austin. 2001. Competitive interactions between tree species in New Zealand's oldgrowth indigenous forests. Ecology 82: 2560-2573.

Legendre, P. \& L. Legendre. 1998. Numerical Ecology. Developments in Environmental Modelling 20. Elsevier, Amsterdam, Holland.

McIvor, C.C. \& W.E. Odum. 1998. Food, predator risk, and microhabitat selection in a marsh fish assemblage. Ecology 69: 1341-1351.

Mac Nally, R.C. 1983. On assessing the significance of interespecific competition to guild structure. Ecol. Soc. Am. 64: 1646-1652.

Mbaiwa, J.E. 2003. The socio-economic and environmental impacts of tourism development on the Okavango Delta, north-western Botswana. J. Arid. Environ. 54: 447-467.

Miller, R.R. 1984. La Media Luna, San Luis Potosí, at edge of Chihuahua Desert, México, p. 67-72. In Proc. Desert Fishes Council. Desert Fishes Council Co. (ed.). Volumes XVI-XVIII. Ann. Symp., Bishop, California, USA.

Mugodo, J., M. Kennard, P. Liston, S. Nichols, S. Linke, R.H. Norris \& M. Lintermans. 2006. Local stream habitat variables predicted from catchment scale characteristics are useful for predicting fish distribution. Hydrobiologia 572: 59-70.

Nogués-Bravo, D. 2003. El estudio de la distribución espacial de la biodiversidad: conceptos y métodos. Cuadernos de Investigación Geográfica 29: 67-82.

Olden, J.D., N. LeRoy, K. Poff \& R. Bestgen. 2006. Lifehistory strategies predict fish invasions and extirpations in the Colorado River basin. Ecol. Monogr. 76: $25-40$.

Palacio-Núñez, J. 1997. Caracterización del ecosistema de la laguna Media Luna, Rioverde, S. L. P. y su influencia en la ornitofauna acuática y ribereña. Tesis de Maestría, Colegio de Postgraduados, Montecillo, México. 
Palacio-Núñez, J., J.R. Verdú, E. Galante, D. JiménezGarcía \& G. Olmos-Oropeza. 2007. Birds and fish bioindicators of tourist disturbance in springs in semi-arid regions in Mexico: a basis for management. Anim. Biodivers. Conserv. 30: 29-41.

Palmer, T.M., M.L. Stanton \& T.P. Young. 2003. Competition and coexistence: exploring mechanisms that restrict and maintain diversity within mutualist guilds. Am. Nat. 162: S63-S79.

Parker, I.M., D. Simberloff, W.M. Lonsdale, K. Goodell, M. Wonham, P.M. Kareiva, M.H. Williamson, B. Von Holle, P.B. Moyle, J.E. Byers \& L. Goldwasser. 1999. Impact: toward a framework for understanding the ecological effects of invaders. Biol. Inv. 1: 3-19.

Pérez-Arteaga, A., S.F. Jackson \& K.J. Gaston. 2005. Priority sites for wildfowl conservation in Mexico. Anim. Conserv. 8: 41-50.

Perry, J.N. 1995. Spatial analysis by distance indices. J. Anim. Ecol. 64: 303-314.

Perry, J.N., E.D. Bell, R.H. Smith \& I.P. Woiwod. 1996 SADIE: software to measure and model spatial pattern. Aspect. Appl. Biol. 46: 95-102.

Perry, J.N. 1998. Measures of spatial pattern and spatial association for insect counts, p. 21- 33. In J. Baumgärtner, P. Brandmayr \& B.F.J. Manly (eds.). Population and community ecology for insect management and conservation. Balkema, Rotterdam, Holland.

Perry, J.N. \& P. Dixon. 2002. A new method for measuring spatial association in ecological count data. Ecoscience 9: 133-141.

Prchalová, M., J. Kubečka, M. Čech, J. Frouzová, V. Draštík, E. Hohausová, T. Jưza, M. Kratochvíl, J. Matěna, J. Peterka, M. Ríha, M. Tušer, M. Vašek. 2009. The effect of depth, distance from dam and habitat on spatial distribution of fish in an artificial reservoir. Ecol. Fresh. Fish: 18: 247-260.

Purchase, C.F. \& J.A. Hutchings. 2008. A temporally stable spatial pattern in the spawner density of a freshwater fish: evidence for an ideal despotic distribution. Can. J. Fish. Aquat. Sci. 65: 382-388

Rahel, F.J. \& J.D. Olden. 2008. Assessing the effects of climate change on aquatic invasive species. Conserv. Biol. 22: 521-533.

Ribeiro, F., B. Elvira, M.J. Collares-Pereira \& P.B. Moyle. 2008. Life-history traits of non-native fishes in Iberian watersheds across several invasion stages: a first approach. Biol. Inv. 10: 89-102
Ribeiro, F., M.J. Collares-Pereira \& P.B. Moyle. 2009. Non-native fish in the fresh waters of Portugal, Azores and Madeira Islands: a growing threat to aquatic biodiversity. Fish. Manag. Ecol. 16: 255-264.

Root, K.V. 1998. Evaluating the effects of habitat quality, connectivity, and catastrophes on threatened species. Ecol. Appl. 8: 854-865.

Schoener, T.W. 1974. Resource partitioning in ecological communities. Science 185: 27-39.

Soto Galera, E. 2003a. Ataeniobius toweri. Elaboración de las fichas técnicas para la evaluación del riesgo de extinción de 18 especies de peces dulceacuícolas mexicanos. Bases de datos SNIB-CONABIO. Proyecto W040. Dpto. de Zoología, E.N.C.B., Instituto Politécnico Nacional, México. D.F.

Soto Galera, E. 2003b. Cualac tessellatus. Elaboración de las fichas técnicas para la evaluación del riesgo de extinción de 18 especies de peces dulceacuícolas mexicanos. Bases de datos SNIB-CONABIO. Proyecto W040. Dpto. de Zoología, E.N.C.B., Instituto Politécnico Nacional, México. D.F.

Soto Galera, E. 2003c. Cichlasoma bartoni. Elaboración de las fichas técnicas para la evaluación del riesgo de extinción de 18 especies de peces dulceacuícolas mexicanos. Bases de datos SNIB-CONABIO. Proyecto W040. Dpto. de Zoología, E.N.C.B., Instituto Politécnico Nacional, México. D.F.

Soto Galera, E. 2003d. Ictalurus mexicanus. Elaboración de las fichas técnicas para la evaluación del riesgo de extinción de 18 especies de peces dulceacuícolas mexicanos. . Bases de datos SNIB-CONABIO. Proyecto W040. Dpto. de Zoología, E.N.C.B., Instituto Politécnico Nacional, México. D.F.

StatSoft Inc. 2001. STATISTICA (Data Analysis Software System) Version 6.

Suárez-Seoane, S., P.E. Osborne \& J.C. Alonso. 2002. Large-scale habitat selection by agricultural steppe birds in Spain: identifying species-habitat responses using generalized additive models. J. Appl. Ecol. 39: 755-771.

Tellería, J.L. 1986. Manual para el censo de los vertebrados terrestres. Raíces, Madrid, España.

Vogt, R.J., T.N. Romanuk \& J. Kolosa. 2006. Species richness-variability relationships in multi-trophic aquatic microcosms. Oikos 113: 55-66.

Werner, E.E. \& J.F. Guilliam. 1984. The ontogenetic niche and species interactions in size-structured populations. Annu. Rev. Ecol. Evol. Syst. 15: 393-425. 
Winemiller, K.O. \& E.R. Pianka. 1990. Organization in natural assemblages of desert lizards and tropical fishes. Ecol. Monogr. 60: 27-56.

\section{ELECTRONIC REFERENCES}

Chick, J.H., M.A. Pegg \& T.M. Koel. 2006. Spatial patterns of fish communities in the Upper Mississippi River System: assessing fragmentation by low-head dams. River Research and Applications 22: 413-427. (Downloaded: July 12, 2009, http://cat.inist.fr/?aMod ele $=$ afficheN\&cpsidt733259).

Espinosa-Pérez, H., M.T. Gaspar-Dillanes \& P. FuentesMata. 1993. Listados faunísticos de México. III. Los peces dulceacuícolas mexicanos. Dpto. de Zoología. Inst. de Biología, UNAM, México.

(Downloaded: May 26, 2006, http://biblio68.ibiologia. unam.mx/FullText-/lf3.html).

INE, 2002. Lista de Especies en Riesgo: Peces. Norma Oficial Mexicana (NOM - 059). Instituto Nacional de Ecología. Anexo Normativo II. Diario Oficial de México, 6 de marzo de 2002. (Downloaded: December 08, 2006, www.ine.gob.mx/ueajei/norma59).

Kleynhans, C.J. 1999. R20: The use of ecological information on fish in the specification of the flow component of the reserve (desktop, rapid, intermediate and comprehensive determinations), p. R20 1 - R20 13. In H. MacKay \& L. Guest (eds.). Resource directed measures for protection water resources: River Ecosistems. Departament of Water Affairs and Forestry, South Africa. (Downloaded: July 13, 2009, http://www.dwaf.gov.za/docs/Water\%20Resource $\% 20$ Protection $\% 20$ Policy/river\%20ecosystems/ riv_appR20_version1.0.doc.)

Maestre, F.T. 2006. Análisis y modelización de datos espacialmente explícitos en ecología. Ecosistemas. (Downloaded: October 02, 2006, www.revistaecosistemas.net/articulo.asp?Id=440\&Id)

Marrow, J.V. Jr. \& C. Fischenich. 2000. Habitat requirements for freshwater fishes. ERDC TN - EMRRP Engineer Research and Development Canter Technical Notes - Ecosyst. Manag. and Rest. Res. (Downloaded: October 06, 2007, http:/quanterion.com/ RIAC/Library/Library.asp)

Quero, J.L. 2006. SADIE como herramienta de cuantificación de la heterogeneidad espacial: casos prácticos en el Parque Nacional de Sierra Nevada, Granada, España. Ecosistemas.

(Downloaded: December 06, 2007, http://www.revistaecosistemas.net/articulo.asp?Id=436\&Id.) 